NBER WORKING PAPER SERIES

\title{
ARE MIGRANTS MORE SKILLED THAN NON-MIGRANTS? \\ REPEAT, RETURN, AND SAME-EMPLOYER MIGRANTS
}

\author{
Jennifer Hunt \\ Working Paper 10633 \\ http://www.nber.org/papers/w10633
NATIONAL BUREAU OF ECONOMIC RESEARCH 1050 Massachusetts Avenue
Cambridge, MA 02138
July 2004

This paper was prepared for the Innis Lecture at the 2004 meetings of the Canadian Economics Association. I thank Barry Chiswick and seminar participants at Syracuse, Texas and the IZA migration conference for very helpful comments. I am also affiliated with the CEPR, IZA, William Davidson Institute, and DIWBerlin. The views expressed herein are those of the author(s) and not necessarily those of the National Bureau of Economic Research.

(C2004 by Jennifer Hunt. All rights reserved. Short sections of text, not to exceed two paragraphs, may be quoted without explicit permission provided that full credit, including $\mathbb{C}$ notice, is given to the source. 
Are Migrants More Skilled than Non-Migrants? Repeat, Return and Same-Employer Migrants Jennifer Hunt

NBER Working Paper No. 10633

July 2004

JEL No. J6

\section{ABSTRACT}

I examine the determinants of inter-state migration of adults within western Germany, using the German Socio-Economic Panel from 1984-2000. I highlight the prevalence and distinctive characteristics of migrants who do not change employers. Same-employer migrants represent one fifth of all migrants, and have higher education and pre-move wages than non-migrants. Conditional on age, same-employer migrants are therefore more skilled than non-migrants. By contrast, although other migrants have higher education than non-migrants, they do not have higher pre-move wages. Furthermore, they have in their ranks disproportionate numbers of the non-employed, unemployed and recently laid off. It therefore seems inappropriate to characterize them as more skilled than nonmigrants. The results for same-employer migrants indicate that skilled workers have a low-cost migration avenue that has not been considered in the previous literature. I also analyze the relation between repeat and return migration and distinguish between short and long-distance migration. I confirm that long-distance migrants are more skilled than short-distance migrants, as predicted by theory, and I show that return migrants are a mix of successes and failures.

Jennifer Hunt

Department of Economics

McGill University

Leacock Building Room 443

855 Sherbrooke Street West

Montreal, QC, H3A 2T7,Canada

and NBER

jennifer.hunt@mcgill.ca 
In this paper I contribute to a literature assessing whether migrants are more skilled than nonmigrants. It is often viewed as self-evident that migration is more beneficial, or at least less detrimental, if it increases the average skill of the population rather than decreasing it. Sending regions or countries speak of brain drain, while some receiving countries have immigration policies designed to select the most skilled applicants. In standard analysis, both the costs and the benefits of migration stem from any differences in average skills between migrants and nonmigrants. If there are no important fixed factors such as land, immigration of people with a distribution of skills similar to that of natives will affect only the scale of the receiving economy in the long run. If the skill distributions are different, groups complementary to the immigrants experience labor market gains, while close substitutes for the immigrants experience losses. Unskilled immigration provides a benefit by lowering the price of unskilled services, for example, allowing the highly skilled to specialize more in their comparative advantage. Parallel analysis applies to emigration. ${ }^{1}$

The scale of the economy may matter, however, if there are increasing returns to scale in production. More relevant to the issue of migrant skills, it is conceivable that returns to scale could be particularly large in specialized high-skill sectors, where a critical mass of rare talent may be necessary. Furthermore, even once a critical mass has been achieved, skilled workers may provide knowledge spillovers to their skilled colleagues, or confer externalities on others in the population..$^{2}$ If the beneficial effects of such skilled workers accrue principally to the host economy, these considerations suggest that an economy should encourage skilled immigration and discourage skilled emigration. ${ }^{3}$ 
The skill mix of migration could also influence economic institutions. For example, it will affect the balance between taxpayers and recipients of transfers ${ }^{4}$, possibly causing tax and benefit systems to be revised. The strength of labor unions could also be affected. ${ }^{5}$

Theoretically, the quality of migrants depends not only on relative migration benefits for the skilled and unskilled, influenced by relative inequality across regions, but also on the relation between skill and moving costs. ${ }^{6}$ Empirical papers have often found that migrants are more educated than non-migrants in the source region, and earned higher wages than non-migrants prior to moving. Examples include Borjas, Bronars and Trejo (1993) for internal U.S. migration, and Hunt (2002) for migration from eastern to western Germany. Chiquiar and Hanson (2002) find Mexican emigrants to the United States to be more educated than Mexican non-emigrants, despite the fact that the United States-Mexico wage gap is higher for the unskilled. They believe their results point to lower moving costs for the more skilled, a point also argued by Chiswick (2000). On the other hand, it is also known that the unemployed, the laid-off, and the nonemployed are more likely to emigrate than the employed. If the unemployed and laid-off are observably or unobservably less skilled than the employed, the results overall point to migrants having more heterogeneous skills than non-migrants. ${ }^{7}$

I replicate these results in my analysis of the determinants of migration by adults between federal states in western Germany. However, I show that the results indicating that many migrants are more skilled than non-migrants are strongly influenced by a group not previously analyzed: migrants who change state of residence without changing employer. Using the German Socio-Economic Panel for 1984-2000, I show that same-employer migrants represent one fifth of all migrants, even though a move must be to a non-contiguous county to be defined as inter-state migration. Same-employer migrants have higher education and higher pre-migration earnings 
than non-migrants. By definition, these migrants were employed before moving, and are therefore clearly more skilled than non-migrants, conditional on age. By contrast, although other migrants have higher education than non-migrants, they do not have significantly higher premove wages. Furthermore, they have in their ranks disproportionate numbers of the nonemployed, unemployed and recently laid off. It therefore seems inappropriate to characterize them as more skilled than non-migrants.

The results for same-employer migrants indicate that skilled workers have a low-cost migration avenue that has not been considered in the previous literature. Same-employer migrants may significantly raise the average skills of migrants in more situations than the one examined here, including migration between rich countries, such as the United States and Canada, or the United States and Germany. They are likely to be less prevalent among migrants from poor to rich countries, however, which might appear to suggest that such migrants could be have skills similar to or worse than those in the source.

Distinguishing between return migrants and "new" migrants, as well as between short and long-distance moves is informative in this regard. Among migrants who are not sameemployer migrants, "new" migrants moving to a non-contiguous state could arguably be characterized as more skilled than non-migrants, conditional on age, while this characterization seems inappropriate for return migrants and "new" migrants moving to a contiguous state. Conditional on education, the last group of migrants is less skilled than stayers. The higher skills of long-distance migrants compared to short-distance migrants confirms the theoretical prediction that migrants will be more skilled when moving costs are high. It is consistent with Schwartz's (1973) finding for white males, and with the finding of Hunt (2002) that commuters are not more skilled than stayers. The result suggests that migrants from poor countries to distant 
rich countries could be skilled by source country standards. Conversely, migrants from poor countries to neighboring rich countries and especially commuters need not be relatively skilled, which may go some way towards explaining the Yashiv (2004) finding of low skills among Palestinians in Israel.

Return migrants who are not same-employer migrants are a heterogeneous group of failures and successes. Laid-off males are very likely to undertake return migration, and return migration accounts for $40 \%$ of the positive influence of layoffs on overall migration. This is consistent with the theory of Borjas and Bratsberg (1996), that some return migrants are marginal migrants whose experience in the destination was worse than expected. ${ }^{8}$ On the other hand, I find that young people with high earnings are also likely to return home. This group has likely undertaken migration as part of a lifecycle plan to raise earnings at home and consume at home, as postulated by Borjas and Bratsberg (1996) and Dustmann $(2001,2003) .^{9}$

Finally, I note the link between repeat and return migration. At least $32 \%$ of all migrants in my sample have moved previously, but more than two-thirds of repeat migrants are returning to a state in which they have previously lived..$^{10}$ I show that two-thirds of the positive effect on migration of previous migration comes through its influence on return moves. The effect of previous migration is often attributed to an unobserved propensity to move, and to the lower opportunity cost of moving if the person in question has less location-specific capital to lose than someone who has never moved. My results show the importance of possible return migration as a variant of the latter explanation: a location with previously established capital is available. ${ }^{11}$ 


\section{Theory}

Chiswick (2000) contains a simple exposition of the human capital investment model of migration, whose origins are in Sjaastad (1962). An individual computes the gross benefit to migration, based on the wage difference in the source and the destination, and compares it with the cost of migration, which could include both foregone earnings and direct costs, such as transport and psychic costs. In the simplest version of the model, the return to skill is the same in the source and destination. If direct costs are equal for all potential migrants, migrants will tend to be those who are better paid, and therefore more skilled, since the return to migration will be higher for such individuals, all else equal. The higher the direct cost, the more positively selfselected the migrants will be. Hence, migrants who move a long distance will be more positively self-selected than migrants who move a short distance. If all moving costs are proportional to the wage, migrants will be similar to non-migrants.

Chiswick's model also shows simply the result developed in Borjas (1987), based on the Roy model, that relative returns to skills (inequality) in the source and destination are important. $^{12}$ If the return to skill is higher in the destination, this factor alone implies a higher return to migration for the more skilled, and hence more positively self-selected migrants: for a given difference in mean country wages, the skilled have a larger potential wage gain from migration. If the return to skill is lower in the destination, this will tend to offset, and possibly even reverse, the positive self-selection of migrants. ${ }^{13}$

In this paper I discuss the self-selection of immigrants as viewed from the source: I consider a migrant to be positively self-selected if he or she is more skilled than non-migrants in the source region, as measured by personal and labor market characteristics, and the wage. Borjas (1987) shows, however, that it is possible for a destination to attract a migrant whose 
skills were below average in the source, yet are above average in the destination ("refugee sorting"). The converse is not possible: migrants whose skills were above average in the source will have above-average skills in the destination.

The question of same-employer migrants has not been considered previously. A firm might request an individual to transfer, or might solicit applications for transfers in particular occupations, or might entertain a request instigated by an individual. In these cases, a firm will most commonly want to transfer workers with skills not available locally at the destination site, which implies transferred workers will be skilled, particularly with regard to firm-specific skills. Alternatively, workers may be transferred for training at another site. Firm-specific skill facilitates intra-firm mobility, contrary to the standard inter-firm case.

Many large firms have internal job markets which allow employees to be well informed about opportunities at other sites. Another site may prefer an applicant already working at the firm, as that applicant has presumably been successfully screened according to the firm's standards. Such transferred workers need not necessarily have scarce observable skills, but are likely to have good unobservable skills.

Typically, firms with multiple sites are large firms, and workers at large firms are paid more than observably equivalent workers at smaller firms. We would therefore expect transferred workers to earn more than others because of their high human capital, and possibly also because of rents associated with large firms.

Migration with the same employer is a low cost and low risk move: information on vacancies is easily available, the conditions of the new job are likely to be known and similar to the old job, skills in the old job are likely to be fully rewarded in the new job and moving costs may even be paid. 


\section{Data}

The sample from the German Socio-Economic Panel (GSOEP) includes both workers and non-workers, aged 18-65, and spans the years $1984-2000 .{ }^{14}$ I focus on inter-state residential moves of residents of western Germany, since east-to-west moves may have somewhat different determinants. ${ }^{15}$ I consider people under 25 moving with parents under sixty, and people moving to an adjacent county across the state border or within a metropolitan area to be non-migrants ("stayers"). Most people who change state but continue to commute daily to the same workplace will be classified as stayers. However, some may move their principal residence while commuting to the old workplace on a weekly basis. Although I have taken pains to identify false moves, I have made no attempt to identify false stays: people who move long distances without changing states. ${ }^{16}$ People moving abroad are recorded as missing observations. The survey will underestimate migration, since movers are generally disproportionately lost by surveys.

In each survey, respondents are asked explicitly whether they had changed job since the beginning of the previous calendar year. If they answer yes, they are asked the nature of the change; a possible answer is a within-firm job-change. I call same-employer migrants those migrants who either said they did not have a job change, or said they had a within-firm change. Many workers genuinely changing workplace may answer that they have no job change, either if their new job is identical to the old, or if they are on a temporary training assignment.

It is likely that some number of respondents classified as same-employer migrants do not in fact change workplace. If these people should properly be classified as stayers, they will bias the same-employer migrant group towards the characteristics of stayers. However, the possibility that people who move a long way for housing or spousal reasons without changing job constitute a distinct group cannot be excluded. It is also possible that some respondents interpret the 
question about a change in job as referring to an occupation. Teachers, for example, whose occupation is slightly overrepresented among same-employer migrants compared to stayers, change employer when they teach in a different state, but may not consider that they have changed jobs. If this is common, the same-employer migrants should be viewed as constituting not only workers transferred by their firm, but also workers who can find jobs in other states so similar to their old job that they do not consider the change to be a job change.

\section{Model}

I begin by estimating probits for the probability that a respondent $i$ changes state of residence $r$ between interviews at $t$ and $t+1, P\left(\right.$ move $\left._{t, t+1}\right)$, as a function of characteristics before the move, $X_{i r t}$, whether the respondent was laid off between the interviews, Laid-off irt,$t+1_{\text {, }}$ whether the respondent had migrated in the previous decade, $M o v e_{i r t^{-}}$, and whether the respondent had completed an educational qualification between the interviews, $E d u_{i r t, t+1}$ :

$$
\mathrm{P}\left(\text { Move }_{\text {irt }, t+1}\right)=X_{\text {irt }} \beta_{1}+\beta_{2} \text { Laid-off }_{\text {irt }, t+1}+\beta_{3} \text { Move }_{\text {irt }}{ }^{-}+\beta_{4} \text { Edu }_{\text {irt }, t+1}+\delta_{r}+\gamma_{t}+\varepsilon_{\text {irt. }}
$$

I also control for year dummies $\gamma_{t}$ and state dummies $\delta_{\mathrm{r}}$. I report marginal effects, and t-statistics adjusted to reflect repeated observations on individuals. I include information on the acquisition of an educational qualification, since many people move after completing a qualification, either to continue their education or take a job. ${ }^{17}$

I subsequently estimate multinomial logits based on this specification. I first divide migrants into three mutually exclusive groups: same-employer migrants, return migrants (who were not same-employer migrants), and others. I then divide the "others" group into those who moved to a neighboring state, and those who moved farther. This gives me four groups of 
migrants and the group of stayers as categories for the multinomial logit. I report odds ratios (exponentiated coefficients) and t-statistics adjusted to reflect repeated observations on individuals.

Same-employer migrants had been working in year $t$, were not laid off between interviews, and with one exception did not report being unemployed (in addition to employed) in year $t$. Therefore, the coefficients on these variables for same-employment migration are constrained to be zero (with an odds ratio of one). When the sample is split by age or sex, the small number with an increase in education requires this coefficient too to be set to zero for same-employer migration. Since there cannot be any return migrants in the first year, the coefficient on the 1984 year dummy is constrained to be zero for return migration.

\section{Descriptive Statistics}

Column 1 of Table 1 shows that the migration rate is $0.67 \%$ per year. ${ }^{18}$ The subsequent columns indicate that the migration rate is twice as high among those under thirty compared to those aged 30-49 (columns 2 and 3), and more than twice as high among those laid off as those not laid off (columns 6 and 7). Men and women have similar migration rates (columns 4 and 5).

In Table 2 I distinguish between same-employer migrants to a new state, and sameemployer return migrants, who represent $18 \%$ and $5 \%$ of moves respectively (column 1$).{ }^{19}$ Other return migrants represent $17 \%$ of migrants, $31 \%$ of migrants moved to a "new" neighboring state, and $29 \%$ moved to a "new" non-contiguous state. A majority of same-employer moves are for people aged 30-49, for whom they represent in total $31 \%$ of moves (column 3), consistent with the notion that these are transferred workers who have accumulated firm-specific 
knowledge. Most of these moves are made by men, for whom they represent $32 \%$ of moves, rather than women, for whom they represent only $15 \%$ of moves (columns 4 and 5).

Table 3 shows the means of the main variables of interest by migrant status, again distinguishing between the two types of same-employer move. The most striking statistic of the table is the share of migrants who had completed tertiary education (university or technical higher education - Fachhochschule). While only $9 \%$ of stayers had completed tertiary education (column 1), $28 \%$ of movers had done so (column 2), while $34 \%$ of same-employer movers to a new state and $49 \%$ of return same-employer movers (columns 6 and 7) had done so. Sameemployer migrants are slightly older than other migrants, and with long-distance movers have the highest pre-move wages (25-28 German marks (DM) per hour, compared to 20 for stayers). Individuals laid off between interviews are overrepresented among movers, particularly among return movers (column 5), where they represent $10 \%$ of the group. I shall assume that they were laid off before moving. $32 \%$ of migrants (column 2) compared to only $3 \%$ of non-migrants (column 1) had moved in the previous ten years, but among non-return migrants, this share is never higher than $15 \%$. A calculation not shown indicates that more than two-thirds of previous movers are return movers. Means of other variables used in the regressions are shown in the Appendix Table.

The two groups of same-employer migrants have similar characteristics, and in multinomial logit analysis the hypothesis that their coefficients were the same could not be rejected. I therefore pool these two groups in the multinomial results reported below.

As expected, same-employer migrants work disproportionately in large firms: $42 \%$ work in firms of over 2000 employees, compared to $27 \%$ of working stayers, and $17-24 \%$ for workers in other migrant groups. The most common and most over-represented occupation for female 
same-employer migrants is "accountants, cashiers and related", who are $16 \%$ of same-employer migrants compared to $9 \%$ in the general female workforce. For male same-employer migrants the most common and most over-represented occupation is "architects and engineers", who are $18 \%$ of the same-employer migrants compared to $4 \%$ in the general male workforce.

\section{Results \\ Probits}

The columns of Table 4 represent a series of probits for the probability of migration, with some variations in the definition of migration. All specifications include controls for sex, marital status, the presence of a child eleven or younger, the interaction of marital status and child with sex, and dummies for foreign nationality, age, year and state, in addition to those shown in the table. The first five columns use the migration definition described in the data section. In column 1 I add education dummies to the basic set of controls. The omitted category is apprenticeship, the most common category. The dummy for the unskilled "general education" category has an insignificant negative coefficient. However, individuals with vocational training, which typically follows an apprenticeship, or civil service training, are a significant $0.15 \%$ more likely to migrate, while those with tertiary education are $1.2 \%$ (1.2 percentage points) more likely to migrate, compared to a mean of only $0.7 \%$. These results suggest that migrants are more skilled than non-migrants. Those that acquired an educational qualification in the current year were $0.28 \%$ more likely to migrate.

In column 2, rather than using education as a proxy for skill, I use the wage in the initial year. This is naturally only valid for those who are working. For the employed, the wage may be the best measure of skills, since it should reflect both observed characteristics and unobserved characteristics such as motivation or firm-specific human capital. Those who are not working are 
$0.28 \%$ more likely to move than those who are working, while amongst those who are working, those with a higher wage are more likely to migrate, indicating that the more skilled workers migrate. The mean hourly wage in the sample, as well as the mean wage of those with apprenticeship education, is DM20 (standard deviation 23), while for tertiary graduates it is DM31. The coefficient of 0.0166 indicates that were the hourly wage to rise by $31-20=11 \mathrm{DM}$ per hour, the probability of migration would rise by $0.18 \%$, only $15 \%$ of the magnitude of the university effect in column 1 .

In column 3 I use labor force status only as a proxy for skill (although the labor force coefficients do not prove very sensitive to the presence of other skill covariates). Similarly to column 2 , those not working are $0.27 \%$ more likely to migrate than the employed. Those registered as unemployed at the time of the initial interview are $0.16 \%$ more likely to migrate than others who were not working, meaning they are $0.27+0.16=0.43 \%$ more likely to move than the employed, about half the mean migration rate. Those laid off between interviews (who would typically have been employed at the time of the initial interview), are $0.51 \%$ more likely to emigrate, about half the size of the university effect.

In column 4 I include education, labor force status and wage, as well as an indicator for working part-time (whose coefficient is insignificant). The main change when the skill indicators are entered simultaneously is that the coefficient on the wage falls to two-thirds of its column 2 level. In column $5 \mathrm{I}$ add the covariate indicating whether the individual had moved in the previous ten years. This is very significant: a previous move raises the probability of a subsequent move by $2.4 \%$, the largest effect identified. The only other coefficient to change appreciably when this covariate is added is the coefficient on university, which falls to two thirds 
of its column 4 level: part of the reason that the university-educated are more likely to move is that they are more likely to have moved in the past.

In columns 6-7 I recode the moves of same-employer migrants to be stays, to assess the influence of this group on the results. I present results from the specifications corresponding to columns 2 and 5. Removing the same-employer migrants in column 6 causes the coefficient on the wage to fall to $40 \%$ of its previous size (in column 2), and increases the standard error. The coefficient is thus not close to significant. If the wage is used as a summary measure of the skill of employed potential migrants, therefore, migrants who are not same-employer migrants are not positively self-selected.

In column 7 I repeat the specification with all covariates including previous move. The coefficient on the wage is here $28 \%$ of its column 5 counterpart and insignificant, and the coefficient on university falls to almost half its column 5 level. The coefficient on vocational training also falls, while the coefficients on not working and being laid off rise (since migrants who by definition were employed and not laid off have been removed). This reinforces the impression that migrants who are not same-employer migrants are not more skilled than nonmigrants. The coefficient on a previous move falls somewhat in column 7 compared to column 5 , suggesting that some of its effect comes from identifying people likely to be mobile sameemployer movers.

In column 8, compared to the standard migration definition, I recode moves of those returning to a state they have lived in the previous decade (who are not same-employer return movers), to be stays. I present the specification corresponding to column 5 . The coefficient which changes the most when returners are recoded is that on a previous move: it falls to an effect of $0.72 \%$, only $30 \%$ as large as the column 5 effect. Thus, most of the effect of a previous 
move works through the fact that previous movers are at risk to return home. Nevertheless, the remaining effect is still quantitatively important, and with university education the strongest predictor of migration. ${ }^{20}$ There is also a large decrease in the coefficient on a layoff: it falls from $0.45 \%$ in column 5 to $0.24 \%$ in column 8 , indicating that layoffs have a strong influence on return migration. The coefficient on not working falls when returns are coded as stays.

\section{Multinomial Logits}

In Table 5 I present the results of the multinomial equivalents of columns 2 and 5 in Table 4. The reference category is non-migration. In columns 1-4 I focus on the wage as a summary of skill. As expected based on the results of the probits, same-employer migrants have significantly higher pre-move wages than stayers: the coefficient indicates that a one DM increase in the hourly wage would increase the relative migration probability by $0.5 \%$, and hence a DM11 increase would increase the migration probability by $5.5 \%$. Long-distance migrants are similarly positively and statistically significantly self-selected. Return migrants have an imprecisely estimated coefficient of zero, while migrants to a neighboring state appear to have lower wages than stayers, but the coefficient is not statistically significant. Compared to the employed, the non-employed have approximately double the relative probability of each type of migration.

In columns 5-8 I include all the skill measures. All migrants are positively self-selected on their education: having tertiary education approximately quadruples the probability of being in one of the migrant categories compared to being a non-migrant (the coefficients are not significantly different across columns). The wage coefficients generally remain unchanged, but the coefficient for short-distance moves falls sufficiently to become significantly negative: 
conditional on education, the employed members of this group are negatively self-selected (column 5). This is the wage effect least dwarfed by the education effect: a DM1 rise in the wage reduces the relative probability of this type of migration by $3 \%$, and a DM11 rise reduces the probability by $33 \%$.

The weak effects of wages relative to education could indicate that the importance of education goes beyond its relation with labor market productivity. An alternative explanation, particularly for short-distant migration for which the wage is significantly negative conditional on education, is that some people migrate because they are underpaid in their current job. This in turn could be a manifestation of Borjas's "refugee sorting". ${ }^{21}$

As expected based on the probits, the magnitude of the layoff effect is greatest for the return migration category. The relative probability of return migration is multiplied by five for a person who is laid off (column 7), compared to a multiple of two for a short-distance move (column 5), and a multiple of three for a long-distance move (column 6). The effects are significantly different at the $10 \%$ level for return and short-distance migration.

Compared to other non-employed, the unemployed are significantly more likely to make a move to a neighboring state only. The total effect of being unemployed is the product of the odds ratios for non-employment and unemployment: compared to the employed, the unemployed are four times $(2.22 \times 1.76$, column 5) more likely to move to a neighboring state than to stay, which is larger than the layoff effect of 2.19 , though insignificantly so. The effect of a layoff and the total effect of unemployment are similar for long-distance moves (odds ratios of 3.7 and 3.1, column 6), but the layoff odds ratio is larger for return moves (5.0 vs 3.8 in column 7 ), though insignificantly so. It is possible that when workers who have the possibility of returning home are laid off, they return immediately without waiting to register for unemployment benefits. 
Those who remain non-employed long enough to be picked up as such by the survey may have made their decision not to return.

Lest the distinctive characteristics of the same-employer migrants be influenced by the unmodelled fact that a respondent must be working for this migration to be an option, I have rerun the regression of columns 5-8 on a sample of people working in the initial year. The (unreported) coefficients on the common coefficients are similar, except that the new layoff coefficients are larger, particularly for return migration.

Table 6 presents the multinomial logit specification of Table 5 columns 5-8 with the sample split by sex. For women, only same-employer migrants have relatively higher wages than stayers (column 8), whereas for men both long-distance movers and same-employer movers have higher wages than stayers (columns 2 and 4). These results suggest the possibility that women moving long distances who are not moving with the same employer are often tied movers. ${ }^{22}$

While for men the effect of a university education is strongest for same-employer moves (column 4, odds ratio of 5.89), for women the same-employer odds ratio of 2.4 is the smallest of the moving categories (column 8). The differences between the university coefficients across categories are not statistically significant for men or women, however.

Also of great interest in Table 6 is the result for men that those laid off are 11.5 times more likely than others to return home relative to staying (column 3). This coefficient is significantly larger than for the other migration categories. The result suggests that men who migrate and fail return home. No such pattern is seen for women, for whom the layoff effect operates exclusively through long-distance moves.

In Table 7 I present the same specifications for a sample split by age. I focus on young people (18-29) and prime-aged people (30-49). Coefficients vary by age for layoffs and the 
wage. Layoffs push the young to return home (column 3 indicates that a layoff increases the relative probability of such a move by five times), while for other moves layoffs have an insignificant effect. Conversely, layoffs have an insignificant effect on return moves for the prime-aged (column 7), but large significant effects of 3.5-6 on other moves (columns 5 and 6). The association between same-employer moves and the wage does not differ much by age, but while long-distance migrants are positively self-selected on the wage among the prime-aged, it is rather return movers who are positively self-selected in the case of the young.

The stronger effect of layoffs on older people for non-return moves confirms the result of Hunt (2002) for east-to-west migration. However, for east-to-west migration, younger migrants were found to be more positively self-selected than older migrants based on the wage, which is not the case here. The wage may be a less good skill proxy for the young, who are in an investment phase, than for the old.

\section{Conclusion}

Skilled migrants have a low-cost avenue for migration that has not previously been considered: transferring within their firm. This should contribute to the positive self-selection of migrants, particularly for internal migration, or migration between rich countries. I show that this avenue is quantitatively important for German internal migration, where a fifth of inter-state migrants move with the same employer. If the wage is used as a summary of skill, these migrants account for the overall positive characteristics of migrants compared to non-migrants.

Migrants who are not same-employer migrants cannot be considered generally more skilled than non-migrants. However, it is important to distinguish further between return and "new" migrants, and short and long-distance migrants. Return migrants are a heterogeneous 
group of failures and successes, in keeping with theory predicting that some return migrants had worse realized outcomes of their initial migration than they had expected, while some had always intended to return. Among "new" migrants, long-distance migrants are positively selfselected, while short-distance migrants are not. This confirms the theory predicting that higher moving costs increase the positive self-selection of migrants. The result suggests that migrants from poor countries to distant rich countries are likely to be positively self-selected, while migrants from poor countries to neighboring rich countries need not be.

Finally, I show that repeat migration is primarily accounted for by return migration. The strong predictive power of a previous move has often been interpreted as reflecting an unobserved propensity to move, or identifying people with low investment in their current location. My result indicates the importance of having a potential destination where previous investments have been made. 


\section{Data Appendix}

I use information about the interview dates and the dates that jobs started to establish whether a respondent had changed job between interviews. I use information on the reason a job ended to assess whether the change had been involuntary (which I term a layoff).

I construct a variable indicating whether the respondent has moved in the previous ten years (or since their entry to the survey, if less than ten years previously), and for migrants, I check whether they have lived in their destination state in the previous ten years (or since entry to the survey). These variables will be underestimated in the early part of the survey, meaning early return migrants will be misclassified, and the effect of a previous move will be biased downward. I compute these variables based on the periods in which I observe respondents in the sample, to avoid having missing values for those who temporarily left the sample.

I construct an hourly wage rate from monthly labor earnings divided by 4.33 times usual weekly hours. Dropping observations with missing wages reduces the sample considerably, but does not change the overall migration rate. I do not drop observations with missing layoff information, since this leads to a disproportionate loss of migrants, but instead include a dummy for having missing layoff information.

The small state of Saarland is not identified separately in the GSOEP, and is treated as part of Rheinland-Pfalz (Rhineland-Palatinate). Detailed geographic information in restricted form is available by agreement with the SOEP Group at the DIW-Berlin. 


\section{References}

Aydemir, Abdurrahman. 2003a. "Estimating the Effects of Immigration Policy: Disentangling Policy Effects from Self-Selection”. Statistics Canada working paper.

Aydemir, Abdurrahman. 2003b. “Are Immigrants Positively or Negatively Selected? The Role of Immigrant Selection Criteria and Self-Selection”. Statistics Canada working paper.

Borjas, George. 1987. "Self-Selection and the Earnings of Immigrants". American Economic Review pp.531-553.

Borjas, George. 1999a. Heaven's Door: Immigration Policy and the American Economy Princeton: Princeton University Press.

Borjas, George. 1999b. "The Economics Analysis of Immigration.” In Orley Ashenfelter and David Card eds. Handbook of Labor Economics Vol.3A Amsterdam: North Holland.

Borjas, George and Bernt Bratsberg. 1996. "Who Leaves? The Outmigration of the Foreign Born." Review of Economics and Statistics Vol. 78 No. 1 pp. 165-176.

Borjas, George, Bronars, Stephen and Stephen Trejo. 1992. "Self-Selection and Internal Migration in the United States". Journal of Urban Economics Vol.32 No.2 pp.159-185.

Borjas, George and Stephen Trejo. 1991. "Immigrant Participation in the Welfare System." Industrial and Labor Relations Review Vol.44 No.2 pp. 195-211.

Burda, Michael and Jennifer Hunt. 2001. "From Reunification to Economic Integration: Productivity and the Labor Market in Eastern Germany". Brookings Papers on Economic Activity Vol.2 pp.1-92.

Chiquiar, Daniel and Gordon Hanson. 2002. "International Migration, Self-Selection, and the Distribution of Wages: Evidence from Mexico and the United States". NBER Working Paper 9242.

Chiswick, Barry. 2000. “Are Immigrants Favorably Self-Selected: An Economic Analysis”. In Caroline Brettel and James F. Hollifield eds. Migration Theory: Talking Across Disciplines New York: Routledge.

Constant, Amélie and Douglas Massey. 2002. "Return Migration by German Guestworkers: Neoclassical versus New Economic Theories." International Migration Vol.40 No.4 pp. 5-38.

Constant, Amélie and Douglas Massey. 2003. "Self-Selection, Earnings, and Out-Migration: A Longitudinal Study of Immigrants to Germany." Journal of Population Economics Vol.16 No.4 pp. 631-653. 
Constant, Amélie and Klaus Zimmermann. 2003. "The Dynamics of Repeat Migration: A Markov-Chain Analysis”. IZA Discussion Paper 885.

Dustmann, Christian. 2003. "Return Migration and the Optimal Migration Duration". European Economic Review. Vol. 47 pp. 353-367, 2003.

Dustmann, Christian. 2001. "Why go back? Return Motives of Migrant Workers". In S. Djajic ed. International Migration: Trends, Policy, and Economic Impacts, New York: Routledge.

Goss, Ernst P. and Niles C. Schoening. 1984. "Search Time, Unemployment, and the Migration Decision”. Journal of Human Resources Vol. 19 (4) pp.570-579.

Gregg, Paul, Stephen Machin, and Alan Manning. 2001. "Mobility and Joblessness”. Centre for Economic Performance, LSE, working paper.

Ham, John, Xianghong Li and Patricia Reagan. 2003. "Propensity Score Matching, a DistanceBased Measure of Migration, and the Wage Growth of Young Men”. Ohio State working paper.

Hughes, Gordon and Barry McCormick. 1981. "Do Council Housing Policies Reduce Migration Between Regions?”. Economic Journal Vol. 91 (364) pp.919-937.

Hunt, Jennifer. 2002. “Why Do People Still Live in East Germany?”. Working Paper.

Kennan, John and James Walker. 2003. "The Effect of Expected Income on Individual Migration Decisions.” NBER Working Paper 9585, March.

Kremer, Michael. 1993. "The O-Ring Theory of Economic Development”. Quarterly Journal of Economics Vol. CVIII No.3 pp. 551-576.

Massey, Douglas and Kristin Espinosa. 1997. "What's Driving Mexico-U.S. Migration? A Theoretical, Empirical, and Policy Analysis." American Journal of Sociology Vol. 102 No. 4 pp. 939-999.

Roemer, John. 2001. “The Non-Parochial Welfare Economics of Migration”. Yale University working paper.

Schwartz, Aba. 1973. "Interpreting the Effect of Distance on Migration" Journal of Political Economy Vol.81 No.5 pp. 1153-1169.

Sjaastad, Larry A. 1962. "The Costs and Returns of Human Migration.” Journal of Political Economy Vol.70 supplement pp.80-93.

SOEP Group. 2001. "The German Socio-Economic Panel (GSOEP) After More Than Fifteen Years - An Overview". In Elke Holst, Dean Lillard and Thomas A. DiPrete eds. Proceedings of the 2000 Fourth International Conference of German Socio-Economic 
Panel Study Users (GSOEP2000), Berlin: Vierteljahreshefte zur Wirtschaftsforschung vol. 70 (1) pp.7-14.

Stark, Oded. 2002. "Inducing human capital formation: migration as a substitute for subsidies." Journal of Public Economics Vol.86 pp. 29-46.

Yashiv, Eran. 2004. “The Self-Selection of Migrant Workers Revisited.” IZA Discussion Paper 1094. 


\section{Endnotes}

${ }^{1}$ See Borjas (1999a) for more on these arguments.

${ }^{2}$ See Kremer (1993), for example.

${ }^{3}$ Stark (2002) shows conditions under which the possibility of emigration stimulates investment in skill enough to raise skill per capita in the sending country.

${ }^{4}$ Borjas and Trejo (1991).

${ }^{5}$ Roemer (2001).

${ }^{6}$ Borjas (1987, 1999), Chiswick (2000).

${ }^{7}$ See also Goss and Schoening (1984), Gregg, Machin and Manning (1997), Hughes and McCormick (1981). Goss and Schoening (1984) find that annual earnings have an insignificant effect on U.S. internal migration.

${ }^{8}$ Constant and Massey $(2002,2003)$ and Constant and Zimmermann (2003) find that employed foreigners in Germany are much less likely to return to their home country than their nonemployed fellow foreigners.

${ }^{9}$ Constant and Massey (2002, 2003), who do not split their sample by age, find that foreigners' earnings in Germany play no role in their decision to return home. Massey and Espinosa (1997) examine return migration in a non-random sample of Mexicans in the United States.

${ }^{10}$ Kennan and Walker (2003) make a similar observation based on the NLSY.

${ }^{11}$ DaVanzo (1978) and Goss and Schoening (1984) are among previous papers to have found a large effect of a prior move on the probability of migration. Constant and Zimmermann (2003) and Massey and Espinosa (1997) study the probability of repeated round-trips between two countries. DaVanzo (1983) distinguishes return and onward migration in a sample where all have moved once.

${ }^{12}$ See also Borjas (1999b).

${ }^{13}$ This framework is likely to explain the negative self-selection of American male applicants for permanent migration to English-speaking Canada found by Aydemir (2003a,b).

${ }^{14}$ See the Data Appendix and SOEP Group (2001) for details on the data. Foreigners are oversampled, which reduces unweighted average education.

${ }^{15}$ East-to-west migration is examined in Burda and Hunt (2001) and Hunt (2002).

${ }^{16}$ Ham et al. (2003) measure migration ideally, by measuring who moves beyond a radius of a certain distance, and show that this influences the results compared to simply using state borders.

${ }^{17}$ Since most moves in a period where an educational qualification was obtained are likely to take place after it is obtained, I control for educational qualifications in $t+1$ rather than $t$ to avoid characterizing migrating graduates as having lower education than is in fact the case.

${ }^{18}$ The weighted rate is $0.80 \%$.

${ }^{19}$ The weighted proportions are $16 \%$ and $7 \%$ respectively.

${ }^{20}$ In results not shown, if same-employer return movers are also coded as stayers, the coefficient on a previous move falls to 0.0034, with a t-statistic of 5.2. If all same-employer movers and returns are coded as stayers, the coefficient falls to 0.0022 with a t-statistic of 5.9.

${ }^{21}$ Hunt (2002) finds a similarly weak effect of the wage compared to education for east-to-west migration.

${ }^{22}$ Interactions of the wage with sex, spouse, and sex times spouse all had insignificant coefficients, however. It is difficult to estimate the multinomial logit on single women only, since the number of moves per category becomes small. 
Table 1: Frequency of Year-to-Year Inter-State Migration

\begin{tabular}{|c|c|c|c|c|c|c|c|}
\hline & $\begin{array}{l}\text { All } \\
\text { (1) }\end{array}$ & $\begin{array}{c}18-29 \\
(2)\end{array}$ & $\begin{array}{c}30-49 \\
\text { (3) }\end{array}$ & $\begin{array}{l}\text { Men } \\
\text { (4) }\end{array}$ & $\begin{array}{c}\text { Women } \\
\text { (5) }\end{array}$ & $\begin{array}{c}\text { Not laid } \\
\text { off } \\
(6)\end{array}$ & $\begin{array}{l}\text { Laid } \\
\text { off } \\
\text { (7) }\end{array}$ \\
\hline & 114,946 & 33,238 & 56,862 & 57,239 & 57,707 & 107,139 & 2,526 \\
\hline$\%$ migrated & $0.67 \%$ & $1.25 \%$ & $0.58 \%$ & $04.66 \%$ & $0.68 \%$ & $0.60 \%$ & $1.43 \%$ \\
\hline
\end{tabular}

Notes: Unweighted means for individuals aged 18-65, unless otherwise specified. "Laid off" means that in the second year of the pair the individual reported having been laid off since the first interview. The sample includes some individuals whose layoff status is unknown. 
Table 2: Types of Year-to-Year Inter-State Migration

\begin{tabular}{lccccccc}
\hline & All & $18-29$ & $30-49$ & Men & Women & $\begin{array}{c}\text { Not laid } \\
\text { off }\end{array}$ & Laid off \\
& $(1)$ & $(2)$ & $(3)$ & $(4)$ & $(5)$ & $(6)$ & $(7)$ \\
\hline New neighbor state & 240 & 142 & 78 & 106 & 134 & 192 & 11 \\
not same employer & $(31 \%)$ & $(34 \%)$ & $(26 \%)$ & $(28 \%)$ & $(34 \%)$ & $(30 \%)$ & $(31 \%)$ \\
New non-neighbor & 219 & 111 & 91 & 95 & 124 & 175 & 13 \\
state, not same & $(29 \%)$ & $(27 \%)$ & $(30 \%)$ & $(25 \%)$ & $(31 \%)$ & $(27 \%)$ & $(36 \%)$ \\
employer & & & & & & & \\
Return state & 134 & 88 & 39 & 57 & 77 & 104 & 12 \\
not same employer & $(17 \%)$ & $(21 \%)$ & $(13 \%)$ & $(15 \%)$ & $(20 \%)$ & $(16 \%)$ & $(33 \%)$ \\
New state & 140 & 64 & 68 & 94 & 46 & 140 & 0 \\
same employer & $(18 \%)$ & $(15 \%)$ & $(23 \%)$ & $(25 \%)$ & $(12 \%)$ & $(22 \%)$ & \\
Return state & 35 & 11 & 23 & 25 & 10 & 35 & 0 \\
same employer & $(5 \%)$ & $(3 \%)$ & $(8 \%)$ & $(7 \%)$ & $(3 \%)$ & $(5 \%)$ & \\
\hline Number of moves & 768 & 416 & 317 & 377 & 391 & 646 & 37 \\
& $(100 \%)$ & $(100 \%)$ & $(100 \%)$ & $(100 \%)$ & $(100 \%)$ & $(100 \%)$ & $(100 \%)$ \\
\hline
\end{tabular}

Notes: Parentheses contain unweighted share for individuals aged 18-65, unless otherwise specified. "Laid off" means that in the second year of the pair the individual reported having been laid off since the first interview. The sample includes some individuals whose layoff status is unknown. 
Table 3: Means by Migration Status and Type of Migration

\begin{tabular}{|c|c|c|c|c|c|c|c|}
\hline & \multirow{3}{*}{$\begin{array}{l}\text { Stayers } \\
\\
\text { (1) }\end{array}$} & \multicolumn{6}{|c|}{ Migrants } \\
\hline & & \multirow{2}{*}{$\begin{array}{l}\text { All } \\
\text { (2) }\end{array}$} & \multirow{2}{*}{$\begin{array}{c}\text { Neighbor } \\
\text { state } \\
\text { (3) }\end{array}$} & \multirow{2}{*}{$\begin{array}{l}\text { Distant } \\
\text { state } \\
(4)\end{array}$} & \multirow{2}{*}{$\begin{array}{l}\text { Return } \\
\text { state } \\
(5)\end{array}$} & \multicolumn{2}{|c|}{ Same employer } \\
\hline & & & & & & $\begin{array}{c}\text { New } \\
\text { state } \\
(6)\end{array}$ & $\begin{array}{l}\text { Return } \\
\text { state } \\
\text { (7) }\end{array}$ \\
\hline $\operatorname{Sex}($ female $=1)$ & 0.50 & 0.51 & 0.56 & 0.57 & 0.57 & 0.33 & 0.29 \\
\hline Age & $\begin{array}{l}39.4 \\
(13)\end{array}$ & $\begin{array}{l}31.6 \\
(10)\end{array}$ & $\begin{array}{l}30.9 \\
(11)\end{array}$ & $\begin{array}{l}31.5 \\
(10)\end{array}$ & $\begin{array}{l}30.1 \\
(10)\end{array}$ & $\begin{array}{l}33.9 \\
(10)\end{array}$ & $\begin{array}{c}35.1 \\
(8)\end{array}$ \\
\hline University & 0.09 & 0.28 & 0.26 & 0.26 & 0.22 & 0.34 & 0.49 \\
\hline Not working & 0.35 & 0.38 & 0.51 & 0.47 & 0.50 & 0 & 0 \\
\hline Unemployed & 0.06 & 0.10 & 0.15 & 0.11 & 0.13 & 0 & 0.02 \\
\hline Hourly wage & 20.4 & 22.2 & 16.3 & 25.0 & 18.4 & 25.4 & 27.6 \\
\hline (if working) & (23) & (34) & (8) & $(53)$ & (8) & (38) & (15) \\
\hline $\begin{array}{l}\text { Laid off } \\
\text { (if non-missing) }\end{array}$ & 0.02 & 0.05 & 0.05 & 0.07 & 0.10 & 0 & 0 \\
\hline Previous move & 0.03 & 0.32 & 0.15 & 0.11 & 1 & 0.15 & 1 \\
\hline Observations & 114,178 & 768 & 240 & 219 & 134 & 162 & 35 \\
\hline
\end{tabular}

Notes. Whether the individual was working or registered as unemployed, and the wage of the employed refer to the initial year of the pair. Education is measured in the second year of the pair, while "laid off" refers to those reporting a layoff between the two interviews. The standard deviations of wages and age are in parentheses. Wages are measured in 1991 DM. 
Table 4: Sensitivity of Determinants of Migration to Same-Employer Migration and Return Migration

\begin{tabular}{|c|c|c|c|c|c|c|c|c|}
\hline & \multicolumn{5}{|c|}{ Standard migration definition } & \multicolumn{2}{|c|}{$\begin{array}{c}\text { Same-employer } \\
\text { migrants are } \\
\text { stayers }\end{array}$} & \multirow{2}{*}{$\begin{array}{l}\text { Returners } \\
\text { are } \\
\text { stayers } \\
(8)\end{array}$} \\
\hline & $(1)$ & $(2)$ & (3) & $(4)$ & $(5)$ & $(6)$ & $(7)$ & \\
\hline $\begin{array}{l}\text { General } \\
\text { schooling }\end{array}$ & $\begin{array}{c}-0.0005 \\
(-1.1)\end{array}$ & -- & -- & $\begin{array}{c}-0.0008 \\
(-0.9)\end{array}$ & $\begin{array}{c}-0.0007 \\
(-1.1)\end{array}$ & -- & $\begin{array}{c}-0.0004 \\
(-0.7)\end{array}$ & $\begin{array}{c}-0.0007 \\
(-0.9)\end{array}$ \\
\hline University & $\begin{array}{l}0.0121 \\
(12.4)\end{array}$ & -- & -- & $\begin{array}{c}0.0114 \\
(12.3)\end{array}$ & $\begin{array}{c}0.0073 \\
(10.9)\end{array}$ & -- & $\begin{array}{c}0.0042 \\
(8.3)\end{array}$ & $\begin{array}{c}0.0080 \\
(11.3)\end{array}$ \\
\hline $\begin{array}{l}\text { Vocational,civil } \\
\text { service training }\end{array}$ & $\begin{array}{l}0.0015 \\
(2.7)\end{array}$ & -- & -- & $\begin{array}{c}0.0014 \\
(2.7)\end{array}$ & $\begin{array}{c}0.0012 \\
(2.7)\end{array}$ & -- & $\begin{array}{c}0.0007 \\
(2.2)\end{array}$ & $\begin{array}{c}0.0012 \\
(2.8)\end{array}$ \\
\hline $\begin{array}{l}\text { Education } \\
\text { increase }\end{array}$ & $\begin{array}{c}0.0028 \\
(3.0)\end{array}$ & -- & -- & $\begin{array}{c}0.0029 \\
(3.1)\end{array}$ & $\begin{array}{c}0.0033 \\
(3.7)\end{array}$ & -- & $\begin{array}{c}0.0023 \\
(3.4)\end{array}$ & $\begin{array}{c}0.0034 \\
(3.9)\end{array}$ \\
\hline Not working & -- & $\begin{array}{c}0.0028 \\
(6.1)\end{array}$ & $\begin{array}{c}0.0027 \\
(5.4)\end{array}$ & $\begin{array}{c}0.0031 \\
(6.1)\end{array}$ & $\begin{array}{c}0.0028 \\
(6.3)\end{array}$ & $\begin{array}{c}0.0038 \\
(9.1)\end{array}$ & $\begin{array}{c}0.0040 \\
(9.8)\end{array}$ & $\begin{array}{c}0.0021 \\
(4.9)\end{array}$ \\
\hline $\begin{array}{l}\text { Work } \\
\text { part-time }\end{array}$ & -- & -- & -- & $\begin{array}{c}0.0005 \\
(0.8)\end{array}$ & $\begin{array}{c}0.0010 \\
(1.5)\end{array}$ & -- & $\begin{array}{c}0.0016 \\
(2.8)\end{array}$ & $\begin{array}{c}0.0008 \\
(1.3)\end{array}$ \\
\hline Unemployed & -- & -- & $\begin{array}{c}0.0016 \\
(2.1)\end{array}$ & $\begin{array}{c}0.0017 \\
(2.4)\end{array}$ & $\begin{array}{l}0.0015 \\
(2.4)\end{array}$ & -- & $\begin{array}{c}0.0011 \\
(2.4)\end{array}$ & $\begin{array}{c}0.0014 \\
(2.2)\end{array}$ \\
\hline Laid off & -- & -- & $\begin{array}{c}0.0051 \\
(4.0)\end{array}$ & $\begin{array}{c}0.0054 \\
(4.5)\end{array}$ & $\begin{array}{c}0.0038 \\
(3.8)\end{array}$ & -- & $\begin{array}{c}0.0050 \\
(5.7)\end{array}$ & $\begin{array}{c}0.0023 \\
(2.3)\end{array}$ \\
\hline $\begin{array}{l}\text { Wage*working } \\
* 1000\end{array}$ & -- & $\begin{array}{c}0.0166 \\
(4.1)\end{array}$ & -- & $\begin{array}{c}0.0111 \\
(2.3)\end{array}$ & $\begin{array}{c}0.0099 \\
(2.3)\end{array}$ & $\begin{array}{c}0.0069 \\
(1.2)\end{array}$ & $\begin{array}{c}0.0028 \\
(0.4)\end{array}$ & $\begin{array}{c}0.0098 \\
(2.4)\end{array}$ \\
\hline Previous move & -- & -- & -- & -- & $\begin{array}{c}0.0243 \\
(21.5)\end{array}$ & -- & $\begin{array}{c}0.0174 \\
(19.6) \\
\end{array}$ & $\begin{array}{c}0.0072 \\
(9.1)\end{array}$ \\
\hline Pseudo $\mathrm{R}^{2}$ & 0.10 & 0.08 & 0.09 & 0.12 & 0.16 & 0.09 & 0.18 & 0.12 \\
\hline
\end{tabular}

Notes: Marginal effects from probits on a sample of 114,946 observations. The t-statistics in parentheses are adjusted to account for repeated observations on the same person, and are computed for the untransformed coefficients. Regressions also include sex, spouse, sex*spouse, child, sex*child, foreign and age dummies, year dummies and state dummies. Columns 3,7 and 8 also contain a dummy for missing layoff information. The omitted education is apprenticeship. In columns 6 and 7 same-employer migrants are coded as stayers rather than migrants. In column 8 return migrants (who are not same-employer migrants), are coded as stayers rather than migrants. 
Table 5: Multinomial Estimation of Determinants of Migration

\begin{tabular}{|c|c|c|c|c|c|c|c|c|}
\hline & $\begin{array}{c}\text { Neighbor } \\
\text { state } \\
(1)\end{array}$ & $\begin{array}{c}\text { Distant } \\
\text { state } \\
(2)\end{array}$ & $\begin{array}{l}\text { Return } \\
\text { state } \\
(3)\end{array}$ & $\begin{array}{c}\text { Same } \\
\text { employer } \\
(4)\end{array}$ & $\begin{array}{c}\text { Neighbor } \\
\text { state } \\
(5)\end{array}$ & $\begin{array}{c}\text { Distant } \\
\text { state } \\
(6)\end{array}$ & $\begin{array}{c}\text { Return } \\
\text { state } \\
(7)\end{array}$ & $\begin{array}{c}\text { Same } \\
\text { employer } \\
(8)\end{array}$ \\
\hline University & -- & -- & -- & -- & $\begin{array}{l}4.13 \\
(7.3)\end{array}$ & $\begin{array}{l}3.90 \\
(6.8)\end{array}$ & $\begin{array}{l}4.26 \\
(5.4)\end{array}$ & $\begin{array}{l}4.67 \\
(7.1)\end{array}$ \\
\hline $\begin{array}{l}\text { Not } \\
\text { working }\end{array}$ & $\begin{array}{l}1.85 \\
(2.5)\end{array}$ & $\begin{array}{l}2.50 \\
(5.9)\end{array}$ & $\begin{array}{l}2.60 \\
(5.0)\end{array}$ & 1 & $\begin{array}{l}2.22 \\
(3.1)\end{array}$ & $\begin{array}{l}3.68 \\
(6.7)\end{array}$ & $\begin{array}{l}3.17 \\
(4.8)\end{array}$ & 1 \\
\hline $\begin{array}{l}\text { Work } \\
\text { part-time }\end{array}$ & -- & -- & -- & -- & $\begin{array}{l}2.17 \\
(2.9)\end{array}$ & $\begin{array}{l}1.28 \\
(0.8)\end{array}$ & $\begin{array}{c}0.79 \\
(-0.5)\end{array}$ & $\begin{array}{l}1.12 \\
(0.4)\end{array}$ \\
\hline $\begin{array}{l}\text { Unemploy- } \\
\text { ed }\end{array}$ & -- & -- & -- & -- & $\begin{array}{l}1.76 \\
(2.5)\end{array}$ & $\begin{array}{l}1.02 \\
(0.1)\end{array}$ & $\begin{array}{l}1.21 \\
(0.6)\end{array}$ & 1 \\
\hline Laid off & -- & -- & -- & -- & $\begin{array}{l}2.19 \\
(2.2)\end{array}$ & $\begin{array}{l}3.09 \\
(3.7)\end{array}$ & $\begin{array}{l}5.02 \\
(4.7)\end{array}$ & 1 \\
\hline $\begin{array}{l}\text { Wage* } \\
\text { working }\end{array}$ & $\begin{array}{l}0.977 \\
(-1.8)\end{array}$ & $\begin{array}{l}1.004 \\
(3.8)\end{array}$ & $\begin{array}{l}1.000 \\
(0.6)\end{array}$ & $\begin{array}{l}1.005 \\
(8.0)\end{array}$ & $\begin{array}{l}0.970 \\
(-2.7)\end{array}$ & $\begin{array}{l}1.004 \\
(2.9)\end{array}$ & $\begin{array}{l}0.998 \\
(-0.5)\end{array}$ & $\begin{array}{l}1.005 \\
(7.6)\end{array}$ \\
\hline Pseudo- $\mathrm{R}^{2}$ & \multicolumn{4}{|c|}{0.10} & \multicolumn{4}{|c|}{0.14} \\
\hline
\end{tabular}

Notes: Odds ratios (exponentiated coefficients) for multinomial logits on a sample of 114,946 observations. The reference category is non-migration. The t-statistics in parentheses are adjusted to account for repeated observations on the same person, and are computed for the untransformed coefficients. Regressions also include sex, spouse, sex*spouse, child, sex*child, foreign and age dummies, year dummies and state dummies. The omitted education is apprenticeship. Columns 5-8 also contain a dummy for missing layoff information and the remaining education dummies. 
Table 6: Multinomial Estimation of Determinants of Migration by Sex

\begin{tabular}{|c|c|c|c|c|c|c|c|c|}
\hline & \multicolumn{4}{|c|}{ Men } & \multicolumn{4}{|c|}{ Women } \\
\hline & $\begin{array}{l}\text { Neighbor } \\
\text { state } \\
\text { (1) }\end{array}$ & $\begin{array}{l}\text { Distant } \\
\text { state } \\
(2)\end{array}$ & $\begin{array}{c}\text { Return } \\
\text { state } \\
\text { (3) }\end{array}$ & $\begin{array}{l}\text { Same } \\
\text { employer } \\
\text { (4) }\end{array}$ & $\begin{array}{l}\text { Neighbor } \\
\text { state } \\
\text { (5) }\end{array}$ & $\begin{array}{c}\text { Distant } \\
\text { state } \\
(6)\end{array}$ & $\begin{array}{l}\text { Return } \\
\text { state } \\
(7)\end{array}$ & $\begin{array}{c}\text { Same } \\
\text { employer } \\
(8)\end{array}$ \\
\hline University & $\begin{array}{l}3.54 \\
(4.3)\end{array}$ & $\begin{array}{l}3.38 \\
(4.3)\end{array}$ & $\begin{array}{l}3.11 \\
(2.7)\end{array}$ & $\begin{array}{l}5.89 \\
(6.8)\end{array}$ & $\begin{array}{l}4.15 \\
(5.3)\end{array}$ & $\begin{array}{l}4.57 \\
(5.5)\end{array}$ & $\begin{array}{l}5.32 \\
(4.7)\end{array}$ & $\begin{array}{l}2.42 \\
(2.1)\end{array}$ \\
\hline Not working & $\begin{array}{l}2.21 \\
(2.1)\end{array}$ & $\begin{array}{l}4.91 \\
(5.3)\end{array}$ & $\begin{array}{l}2.21 \\
(1.9)\end{array}$ & 1 & $\begin{array}{l}2.27 \\
(2.2)\end{array}$ & $\begin{array}{l}1.92 \\
(1.9)\end{array}$ & $\begin{array}{l}4.20 \\
(4.4)\end{array}$ & 1 \\
\hline $\begin{array}{l}\text { Work } \\
\text { part-time }\end{array}$ & $\begin{array}{l}4.09 \\
(3.3)\end{array}$ & $\begin{array}{l}3.18 \\
(2.2)\end{array}$ & $\begin{array}{l}1.11 \\
(0.1)\end{array}$ & $\begin{array}{c}0.33 \\
(-1.1)\end{array}$ & $\begin{array}{l}1.77 \\
(1.6)\end{array}$ & $\begin{array}{c}0.85 \\
(-0.4)\end{array}$ & $\begin{array}{c}0.97 \\
(-0.1)\end{array}$ & $\begin{array}{l}1.71 \\
(1.5)\end{array}$ \\
\hline $\begin{array}{l}\text { Unemploy- } \\
\text { ed }\end{array}$ & $\begin{array}{l}1.51 \\
(1.1)\end{array}$ & $\begin{array}{l}1.28 \\
(0.7)\end{array}$ & $\begin{array}{c}0.95 \\
(-0.1)\end{array}$ & 1 & $\begin{array}{l}1.96 \\
(2.3)\end{array}$ & $\begin{array}{c}0.79 \\
(-0.6)\end{array}$ & $\begin{array}{l}1.41 \\
(0.9)\end{array}$ & 1 \\
\hline Laid off & $\begin{array}{l}3.48 \\
(2.7)\end{array}$ & $\begin{array}{l}2.07 \\
(1.4)\end{array}$ & $\begin{array}{l}11.5 \\
(6.3)\end{array}$ & 1 & $\begin{array}{l}1.16 \\
(0.2)\end{array}$ & $\begin{array}{l}3.84 \\
(3.5)\end{array}$ & $\begin{array}{c}0.65 \\
(-0.4)\end{array}$ & 1 \\
\hline $\begin{array}{l}\text { Wage* } \\
\text { working }\end{array}$ & $\begin{array}{l}0.971 \\
(-2.0)\end{array}$ & $\begin{array}{l}1.005 \\
(3.9)\end{array}$ & $\begin{array}{l}0.996 \\
(-0.5)\end{array}$ & $\begin{array}{l}1.004 \\
(5.7)\end{array}$ & $\begin{array}{l}0.971 \\
(-1.7)\end{array}$ & $\begin{array}{l}0.978 \\
(-1.3)\end{array}$ & $\begin{array}{l}0.996 \\
(-0.5)\end{array}$ & $\begin{array}{l}1.006 \\
(5.9)\end{array}$ \\
\hline $\begin{array}{l}\text { Pseudo-R }{ }^{2} \\
\text { Observations }\end{array}$ & \multicolumn{4}{|c|}{$\begin{array}{c}0.14 \\
57239\end{array}$} & \multicolumn{4}{|c|}{$\begin{array}{c}0.14 \\
57.707\end{array}$} \\
\hline
\end{tabular}

Notes: Odds ratios (exponentiated coefficients) for multinomial logits on a sample of 114,946 observations. The reference category is non-migration. The t-statistics in parentheses are adjusted to account for repeated observations on the same person, and are computed for the untransformed coefficients. Regressions also include spouse, child, foreign and age dummies, year dummies and state dummies (Hamburg and Bremen are grouped with Niedersachsen), a dummy for missing layoff information and two additional education dummies. The omitted education is apprenticeship. 
Table 7: Multinomial Estimation of Determinants of Migration by Age

\begin{tabular}{|c|c|c|c|c|c|c|c|c|}
\hline & \multicolumn{4}{|c|}{ Age 18-29 } & \multicolumn{4}{|c|}{ Age $30-49$} \\
\hline & $\begin{array}{c}\text { Neighbor } \\
\text { state } \\
(1)\end{array}$ & $\begin{array}{c}\text { Distant } \\
\text { state } \\
(2)\end{array}$ & $\begin{array}{c}\text { Return } \\
\text { state } \\
(3)\end{array}$ & $\begin{array}{c}\text { Same } \\
\text { employer } \\
(4)\end{array}$ & $\begin{array}{c}\text { Neighbor } \\
\text { state } \\
(5)\end{array}$ & $\begin{array}{c}\text { Distant } \\
\text { state } \\
(6)\end{array}$ & $\begin{array}{c}\text { Return } \\
\text { state } \\
(7)\end{array}$ & $\begin{array}{c}\text { Same } \\
\text { employer } \\
(8)\end{array}$ \\
\hline \multirow[t]{2}{*}{ University } & 3.71 & 4.93 & 3.09 & 4.59 & 5.05 & 3.79 & 4.43 & 4.64 \\
\hline & $(4.4)$ & $(5.1)$ & $(2.7)$ & $(4.1)$ & $(5.2)$ & $(5.0)$ & $(3.5)$ & $(5.5)$ \\
\hline \multirow[t]{2}{*}{ Not working } & 1.76 & 2.21 & 3.66 & 1 & 2.31 & 5.59 & 2.84 & 1 \\
\hline & $(1.7)$ & $(2.2)$ & $(4.7)$ & & $(1.6)$ & $(5.1)$ & $(1.9)$ & \\
\hline Work & 3.28 & 1.77 & 1.10 & 0.90 & 1.73 & 1.31 & 0.73 & 1.25 \\
\hline part-time & $(3.4)$ & $(1.2)$ & $(0.1)$ & $(-0.2)$ & $(1.2)$ & $(0.6)$ & $(-0.4)$ & $(0.6)$ \\
\hline \multirow[t]{2}{*}{ Unemployed } & 1.46 & 1.25 & 0.66 & 1 & 2.37 & 0.76 & 1.69 & 1 \\
\hline & $(1.2)$ & $(0.7)$ & $(-0.9)$ & & $(2.1)$ & $(-0.6)$ & $(1.1)$ & \\
\hline \multirow[t]{2}{*}{ Laid off } & 1.48 & 1.86 & 5.04 & 1 & 3.53 & 5.78 & 2.53 & 1 \\
\hline & $(0.8)$ & $(1.2)$ & $(4.0)$ & & $(2.4)$ & $(4.5)$ & $(1.2)$ & \\
\hline Wage* & 0.951 & 0.980 & 1.003 & 1.005 & 0.972 & 1.007 & 0.976 & 1.006 \\
\hline working & $(-2.6)$ & $(-0.9)$ & $(2.3)$ & $(4.4)$ & $(-2.2)$ & $(4.2)$ & $(-1.3)$ & $(4.5)$ \\
\hline Pseudo- $\mathrm{R}^{2}$ & \multicolumn{4}{|c|}{0.11} & \multicolumn{4}{|c|}{0.14} \\
\hline Observations & \multicolumn{4}{|c|}{33,238} & \multicolumn{4}{|c|}{51,224} \\
\hline
\end{tabular}

Notes: Odds ratios (exponentiated coefficients) for multinomial logits on a sample of 114,946 observations. The reference category is non-migration. The t-statistics in parentheses are adjusted to account for repeated observations on the same person, and are computed for the untransformed coefficients. Regressions also include sex, spouse, sex*spouse, child, sex*child, foreign and age dummies, year dummies and state dummies (Hamburg and Bremen are grouped with Niedersachsen), a dummy for missing layoff information, and two additional education dummies. The omitted education is apprenticeship. 
Appendix Table: Additional Means

\begin{tabular}{|c|c|c|c|c|c|c|c|}
\hline & \multirow{3}{*}{$\begin{array}{c}\text { Stayers } \\
\text { (1) }\end{array}$} & \multicolumn{6}{|c|}{ Migrants } \\
\hline & & \multirow[t]{2}{*}{ All } & \multirow{2}{*}{$\begin{array}{l}\text { Neighbor } \\
\text { state }\end{array}$} & \multirow{2}{*}{$\begin{array}{l}\text { Distant } \\
\text { state }\end{array}$} & \multirow{2}{*}{$\begin{array}{l}\text { Return } \\
\text { state }\end{array}$} & \multicolumn{2}{|c|}{ Same employer } \\
\hline & & & & & & $\begin{array}{c}\text { New } \\
\text { state } \\
(6)\end{array}$ & $\begin{array}{c}\text { Return } \\
\text { state } \\
(7)\end{array}$ \\
\hline Spouse & 0.66 & 0.36 & 0.34 & 0.35 & 0.34 & 0.41 & 0.43 \\
\hline $\begin{array}{l}\text { Sex (female) } \\
\text { * spouse }\end{array}$ & 0.34 & 0.19 & 0.21 & 0.21 & 0.23 & 0.11 & 0.09 \\
\hline $\begin{array}{l}\text { Child age } 0-11 \\
\text { in household }\end{array}$ & 0.31 & 0.25 & 0.25 & 0.28 & 0.23 & 0.21 & 0.29 \\
\hline $\begin{array}{l}\text { Sex (female)* } \\
\text { child age } 0-11\end{array}$ & 0.16 & 0.14 & 0.17 & 0.18 & 0.16 & 0.04 & 0.03 \\
\hline Foreign & 0.26 & 0.14 & 0.16 & 0.14 & 0.13 & 0.13 & 0.09 \\
\hline Age $18-21$ & 0.09 & 0.11 & 0.11 & 0.13 & 0.13 & 0.06 & 0.03 \\
\hline Age $22-25$ & 0.10 & 0.20 & 0.24 & 0.18 & 0.24 & 0.15 & 0.03 \\
\hline Age 26-29 & 0.10 & 0.24 & 0.24 & 0.20 & 0.28 & 0.24 & 0.26 \\
\hline Age 30-39 & 0.15 & 0.20 & 0.19 & 0.25 & 0.14 & 0.19 & 0.23 \\
\hline Age $40-49$ & 0.21 & 0.15 & 0.12 & 0.14 & 0.10 & 0.23 & 0.34 \\
\hline Age $50-59$ & 0.19 & 0.06 & 0.05 & 0.05 & 0.05 & 0.09 & 0.09 \\
\hline Age $60-65$ & 0.15 & 0.05 & 0.05 & 0.05 & 0.04 & 0.03 & 0.03 \\
\hline $\begin{array}{l}\text { General } \\
\text { schooling }\end{array}$ & 0.33 & 0.22 & 0.23 & 0.23 & 0.27 & 0.15 & 0.06 \\
\hline University & 0.09 & 0.28 & 0.26 & 0.26 & 0.22 & 0.34 & 0.49 \\
\hline Apprenticeship & 0.39 & 0.32 & 0.33 & 0.30 & 0.35 & 0.32 & 0.26 \\
\hline $\begin{array}{l}\text { Vocational, civil } \\
\text { service training }\end{array}$ & 0.19 & 0.18 & 0.17 & 0.21 & 0.16 & 0.19 & 0.20 \\
\hline $\begin{array}{l}\text { Education } \\
\text { increase }\end{array}$ & 0.02 & 0.08 & 0.13 & 0.05 & 0.04 & 0.08 & 0 \\
\hline Work part-time & 0.08 & 0.07 & 0.09 & 0.06 & 0.04 & 0.06 & 0.09 \\
\hline Laid off & 0.02 & 0.05 & 0.05 & 0.06 & 0.09 & 0 & 0 \\
\hline $\begin{array}{l}\text { Missing layoff } \\
\text { information }\end{array}$ & 0.05 & 0.11 & 0.15 & 0.14 & 0.13 & 0 & 0 \\
\hline Wage*working & $\begin{array}{l}13.2 \\
(21)\end{array}$ & $\begin{array}{l}13.7 \\
(29)\end{array}$ & $\begin{array}{c}7.9 \\
(10)\end{array}$ & $\begin{array}{l}13.1 \\
(41)\end{array}$ & $\begin{array}{c}9.2 \\
(11)\end{array}$ & $\begin{array}{l}25.4 \\
(38)\end{array}$ & $\begin{array}{l}27.6 \\
(16)\end{array}$ \\
\hline
\end{tabular}

Notes: Unweighted means of 114,178 stayers and 768 migrants. Variables refer to the initial year of the pair, except education, which refers to the second year. "Laid off" refers to those reporting a layoff between the two interviews. The standard deviation of wages interacted with working is reported in parentheses. Means of other variables are shown in Table 2. Wages are in 1991 DM. 